\title{
Effects of overexpression of CXCL10 (cytokine-responsive gene-2) on MA-10 mouse Leydig tumor cell steroidogenesis and proliferation
}

\author{
Madan L Nagpal ${ }^{1,3}$, Yue Chen ${ }^{1,3,4}$ and Tu Lin ${ }^{1,2,3}$ \\ ${ }^{1}$ Research Service, W J B Dorn Veterans Medical Center, Columbia, South Carolina 29209, USA \\ 2Primary Care and Speciality Medicine, W J B Dorn Veterans Medical Center, Columbia, South Carolina 29209, USA \\ ${ }^{3}$ Department of Medicine, University of South Carolina School of Medicine, Columbia, South Carolina 29208, USA \\ ${ }^{4}$ Department of Biology, School of Science, Shantou University, Shantou, Guangdong, China \\ (Requests for offprints should be addressed to T Lin, Department of Medicine, University of South Carolina School of Medicine, Medical Library Building, \\ Suite 316, Columbia, South Carolina 29208, USA; Email: lin@gw.med.sc.edu)
}

\begin{abstract}
Chemokines have been implicated in tumor growth, angiogenesis, metastasis and the host immune response to malignant cells. Infection and autoimmune disorders can reduce androgen production by Leydig cells and adversely affect spermatogenesis. Cytokine-responsive gene-2 (crg-2) (systematic name CXCL10, also known as interferon- $\gamma$-inducible protein 10 (IP-10)) is a potent chemokine expressed predominantly by macrophages and Leydig cells in the testis. CXCL10 binds to CXCR3 receptor (a G-protein-coupled receptor) and acts via Gia protein. We have shown previously that CXCL10 is differentially expressed in normal Leydig cells, inhibited by human chorionic gonadotropin and induced by interferon- $\gamma$, interleukin- $1 \alpha$ and tumor necrosis factor- $\alpha$. The purpose of the present study was to determine the effects of overexpression of CXCL10 by transfection experiments in MA-10 cells on cell growth, CXCR3 expression, progesterone synthesis and steroidogenic acute regulatory protein (StAR D1, a key regulatory factor in steroidogenesis) gene expression. We cloned the complete CXCL10 cDNA in a mammalian expression vector with the CMV promoter, pcDNA3-1D/V5-His-TOPO, and confirmed its expression with rat CXCL10 antibody and V5 antibody. Results showed large amounts of CXCL10 protein secreted in the medium in the CXCL10
\end{abstract}

transfectants by Western blotting. The production of CXCL10 mRNA ranged from 30-50-fold more $(n=6)$ in the transfected cells than the control cells, as determined by semiquantitative and real-time RT-PCR. 8-Br-cAMP downregulated CXCL10 mRNA expression and stimulated CXCR 3 mRNA expression. Transfection of MA-10 cells with CXCL10 decreased cAMP-induced progesterone synthesis from $38.5 \pm 1.7 \mathrm{ng} / \mathrm{ml}\left(1.5 \times 10^{5}\right.$ cells $\left./ \mathrm{ml}\right)$ in control cells to $23 \cdot 2 \pm 1 \cdot 5 \mathrm{ng}$ in transfected cells $(P<0 \cdot 01)$. 8-Br-cAMP $(0 \cdot 2 \mathrm{mM})$-induced StAR D1 mRNA was decreased $30-40 \%$ by transfection with CXCL10. Interestingly, overexpression of CXCL10 induced the expression of its receptor CXCR3 gene, as determined by RT-PCR and fluorescence-activated cell sorter (FACS) analysis. Transfection of CXCL10 also significantly decreased insulin-like growth factor-I (IGF-I, $100 \mathrm{ng} /$ $\mathrm{ml}$ )-induced $\left[{ }^{3} \mathrm{H}\right]$ thymidine incorporation into DNA. These data suggest that CXCL10 also inhibits MA-10 tumor cell proliferation. In conclusion, CXCL10 inhibits StAR D1 expression, decreases progesterone synthesis and inhibits cell proliferation. CXCL10 has the potential to be used in gene therapy for prostate cancer due to its antiangiogenic effect and its inhibitory effect on steroidogenesis.

Journal of Endocrinology (2004) 183, 585-594

\section{Introduction}

Leydig cells in the testis are responsible for the production of androgens needed for spermatogenesis and development of male characteristics. The testis is a dynamic tissue, containing many cell types that produce a variety of compounds that affect Leydig cell function. CXCL10 (cytokine-responsive gene-2) has been shown to be secreted by Leydig cells, macrophages and $\mathrm{T}$ cells into the microenvironment of the testis (Hu et al. 1998, Goffic et al. 2002). CXCL10 has also been shown to exhibit potent antiangiogenic and antitumor activities in vitro and in vivo (Angiolillo et al. 1995, Farber 1997). The overexpression of CXCL10 in combination with IL-12 could be used as a gene therapy to enhance tumor regression (Palmer et al. 2001).

CXCL10 belongs to a large family of chemotactic cytokines, now termed 'chemokines', that are expressed in 
diverse cell types wherein they regulate innate and adaptive immune responses (Murphy et al. 2000). Chemokines are chemotactic factors and growth regulators, which exert their effects through seven transmembrane-domain, G protein-coupled receptors (Farber 1997, Tamaru et al. 1998). The action of CXCL10 is mediated by its receptor CXCR3, as well as by its nonspecific binding to heparan sulfate proteoglycans and unknown novel receptors (Soejima \& Rollins 2001). Ligand binding leads to rapid elevation of intracellular $\mathrm{Ca}^{2+}$ and activation of several other intracellular signaling pathways (Ganju et al. 1998).

CXCL10 has been cloned from humans, mice and rats (Ohmori \& Hamilton 1990, Vanguri \& Farber 1990, Luster et al. 1995, Wang et al. 1996). The murine CXCL10 gene is known as 'cytokine responsive gene-2' (crg-2), whereas rat CXCL10 gene is called 'mob-1'. The CXCL10 gene consists of four exons. The CXC in CXCL10 is CysAsnCys. The murine or rat CXCL10 protein consists of 98 amino acids, with a calculated molecular weight of 10781 (Vanguri \& Farber 1990, Wang et al. 1996). Recently, the NMR structure of CXCL10 has been determined. It consists of a series of loops and one turn of a 3-10 helix at the N-terminus, followed by three antiparallel $\beta$-strands packed against a c-terminal $\alpha$-helix, with two pairs of conserved cysteines, 9-36 and 11-53, that form disulfide bonds (Booth et al. 2002).

It has been well documented that interferon (IFN)- $\gamma$ and tumor necrosis factor (TNF) $\alpha$ secreted by macrophages induce IP-10 (interferon- $\gamma$-inducible protein 10) expression in macrophages and T cells (Narumi 1992, Ohmori et al. 1993, Ohmori \& Hamilton 1995, Sgadari et al. 1996). We have previously demonstrated that CXCL10 is induced by IFN- $\gamma$, interleukin-1 $\alpha$ (IL-1 $\alpha$ ) and TNF- $\alpha$, but inhibited by human chorionic gonadotropin (hCG) in Leydig cells, and causes inhibition of hCG-induced testosterone production. In this paper, we investigated the effect of overproduction of CXCL10 by transient transfection of MA-10 cells on expression of its receptor CXCR3, progesterone production, cell proliferation and expression of the rate-limiting step for steroidogenesis, StAR D1.

\section{Materials and Methods}

\section{Cloning the mouse CXCL10 gene in a mammalian high-expression vector}

Mouse Leydig MA-10 cells (a generous gift from Dr Mario Ascoli, Department of Pharmacology, University of Iowa College of Medicine, Iowa, IA, USA) were cultured in Waymouth's MB/752 medium containing 15\% horse serum. Cells were stimulated with murine (m)IFN- $\gamma(100$ $\mathrm{IU} / \mathrm{ml}, \mathrm{R} \& \mathrm{D}$ Systems, Minneapolis, MN, USA) for $16 \mathrm{~h}$, and total RNA was isolated with Trizol reagent (Life Technologies, Gaithersburg, MD, USA). RNA was treated with ribonuclease-free DNaseI (Life Technologies) to remove any contaminating DNA. The published sequence for mouse CXCL10 (GenBank accession no. J05576) was used to derive PCR primers (sense, $5^{\prime}$-caccat gaacccaagtgctgccgt-3'; antisense, 5'-aggagcccttttagacctttt ttg- $3^{\prime}$ ), incorporating a Kozak consensus sequence (Kozak 1991). The CXCL10 gene was cloned into pcDNA3·1D/ V5-His-TOPO vector (Invitrogen, Carlsbad, CA, USA) containing CMV promoter. The resultant expression plasmid was designated as pCMV-CXCL10-V5, in which the CXCL10 with a V5 epitope of 14 amino acids was driven by a CMV promoter. The cloned gene with V5 epitope was sequenced, using $\mathrm{T} 7$ promoter/priming site and $\mathrm{BGH}$ reverse priming site, with the ABI Prism 310 autosequencer (Applied Biosystems, Foster City, CA, USA) by the Oligonucleotide Facility, University of South Carolina, to establish the direction of cloning and correctness of the sequence. Further tests were carried out by restriction mapping.

\section{Transfection of cells with $p C M V$-CXCL10-V5}

The pCMV-CXCL10-V5 plasmid DNA was amplified and purified with Wizard Maxipreps (Promega). Cells were transfected with $5 \mu \mathrm{g}$ plasmid DNA in FUGENE 6 reagent (Roche Diagnostics, Indianapolis, IN, USA) for $48 \mathrm{~h}$. The cells were further treated with 8-bromo-cAMP or insulin-like growth factor-I (IGF-I) for various time periods and harvested, and the medium and harvested cells were stored at $-80{ }^{\circ} \mathrm{C}$ for further analysis.

\section{Isolation of total RNA and comparative RT-PCR}

Total RNA was extracted from samples with Trizol reagent, and treated with ribonuclease-free DNaseI to remove any contaminating DNA. The purity and yield of isolated RNA were determined by absorbance at 260 and $280 \mathrm{~nm}$. The integrity of the RNA was confirmed by performing denaturing gel electrophoresis. cDNA was generated with $5 \mu \mathrm{g}$ total RNA, $2.5 \mu \mathrm{g}$ oligo-dT primer and mouse Moloney leukemia virus reverse transcriptase (Fisher Scientific, Suwance, GA, USA) at $42{ }^{\circ} \mathrm{C}$ for $1 \mathrm{~h}$. Total cDNA (1/20 of the reaction) was used as the template for PCR. RT-PCR of the S14 ribosomal gene (a housekeeping gene) was amplified by the primer pairs, $5^{\prime}$-tttggtgtctgccacatctttg- $3^{\prime}$ forward and $5^{\prime}$-atgggggtgacatc ctcaat-3' reverse (GenBank accession no. 25070169), giving an amplification product of $323 \mathrm{bp}$ (Mamchaoui et al. 2002). The CXCR3 primers used, matched with mouse and rat GenBank sequences (accession nos. 3798731 (mouse) and 8572056 (rat)), were as follows: $5^{\prime}$-gcctttcttctggaaaacagc-3' forward and $5^{\prime}$-tgctgctcagggc agtgcgc- $3^{\prime}$ reverse, yielding an amplicon of $211 \mathrm{bp}$. StAR D1 primers were selected from the aligned sequences of mouse (accession no. 26386863) and rat (accession no. 1236242) StAR D1; that is, $5^{\prime}$-gcagcaggcaacctggtg-3' 


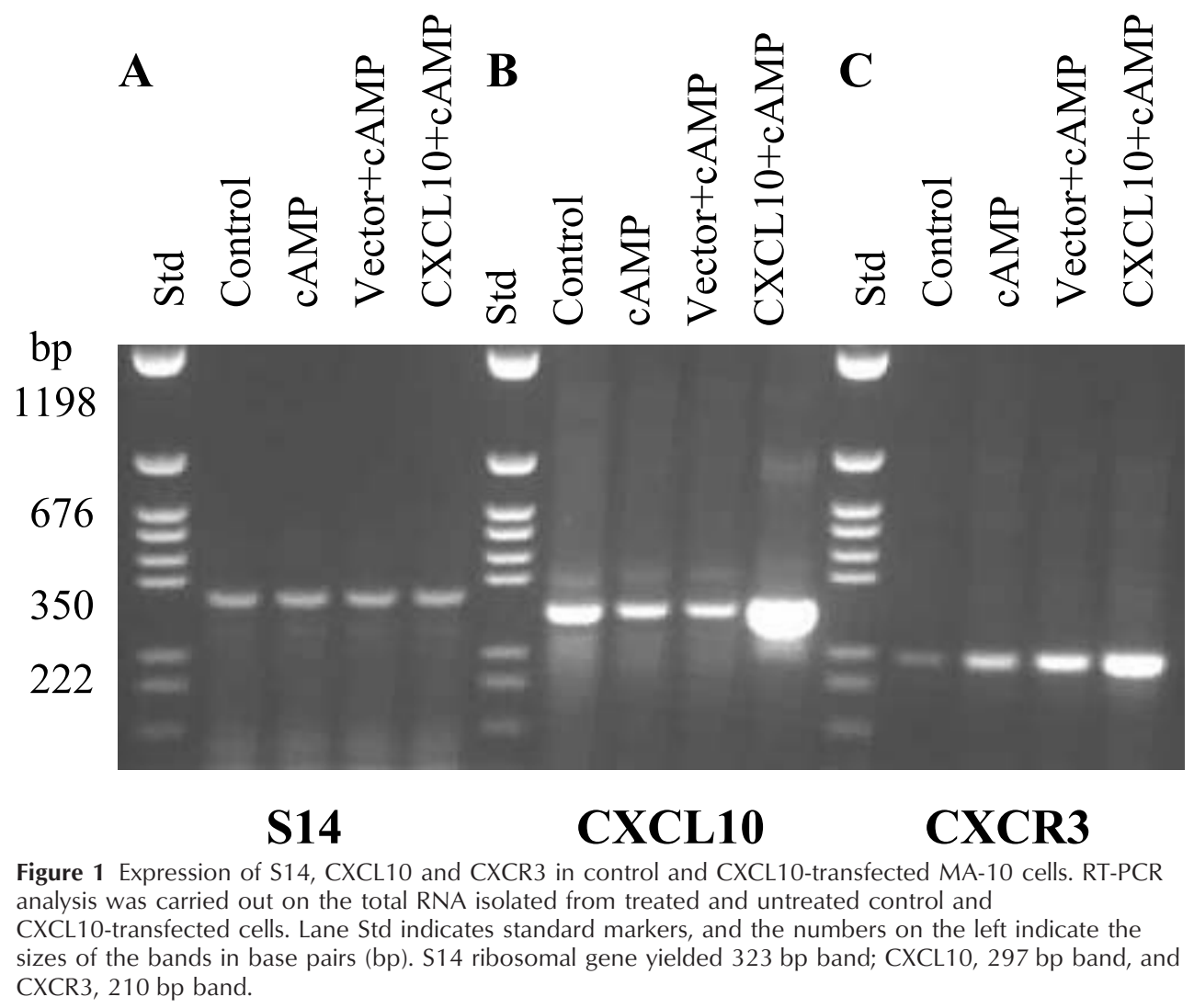

forward and $5^{\prime}$-tgattgtcttcggcagcc-3', yielding an amplification product of $247 \mathrm{bp}$. PCR conditions were optimized with buffers for the PCR system (Stratagene, La Jolla, CA, USA). The amplification reaction buffer also contained $0 \cdot 2 \mathrm{mM}$ of each dNTP, $10 \mathrm{pM}$ of each primer, cDNA template and $1.5 \mathrm{U}$ pfu DNA polymerase. The amplification were carried out with PTC-200 (MJ Research, Waltham, MA, USA). Cycling programs were $94{ }^{\circ} \mathrm{C}$ for $2 \mathrm{~min}$, followed by $26-40$ cycles of $94^{\circ} \mathrm{C}$ for $30 \mathrm{~s}, 48^{\circ} \mathrm{C}$ for $30 \mathrm{~s}$ and $72{ }^{\circ} \mathrm{C}$ for $1.5 \mathrm{~min}$, with a final extension of $72{ }^{\circ} \mathrm{C}$ for $4 \mathrm{~min}$. All experiments were repeated at least three times with comparable results.

\section{Real-time quantitative PCR}

Real-time quantitative PCR amplification reactions were carried out with the MyiQ system (BioRad Laboratories, Hercules, CA, USA), which incorporates a 96-channel optical unit. The reaction mixture consisted of $1 \times \mathrm{PCR}$ buffer containing SYBR-Green; $3 \mathrm{mM} \mathrm{MgCl}_{2}, 100 \mathrm{nM}$ of each primer, $0.2 \mathrm{mM}$ of each dNTP, iTaq DNA polymerase (hot-start enzyme) 25 units/ml, $10 \mathrm{nM}$ SYBR Green and stabilizers. Fifty nanograms cDNA template were added to each reaction. The final volume was adjusted to $20 \mu \mathrm{l}$ with $\mathrm{H}_{2} \mathrm{O}$. The PCR conditions were as follows: $95{ }^{\circ} \mathrm{C}, 8: 30 \mathrm{~min}$; 48 cycles of $95{ }^{\circ} \mathrm{C}, 0: 30 \mathrm{~min}$;
$60{ }^{\circ} \mathrm{C}, 0: 30 \mathrm{~min} ; 72{ }^{\circ} \mathrm{C}, 1: 00 \mathrm{~min}$. To distinguish specific amplicons from nonspecific amplifications, a melt curve was generated. Standard curves were generated for S14 and StAR D1.

\section{Progesterone assay}

MA-10 cells $\left(1 \times 10^{5}\right.$ cells $)$ were seeded onto 12 -well plates in six replicates, and subjected to transient transfection with $5 \mu \mathrm{g}$ pCMV-CXCL10-V5 or pCDNA3-1 (vector) for $48 \mathrm{~h}$. The medium was replaced with $1 \mathrm{ml}$ assay medium (Waymouth's MB/752 medium containing $0 \cdot 1 \mathrm{mg} / \mathrm{ml}$ bovine serum albumin, $\mathrm{pH} 7 \cdot 4$ ), with or without $0.2 \mathrm{mM} 8$-Br-cAMP, and incubated for $16 \mathrm{~h}$ at $37^{\circ} \mathrm{C}$. The medium was collected for progesterone assay, and the cell monolayer was used for the preparation of total cellular protein. The steroids were extracted from the medium by mixing one volume of medium with 10 volumes of diethylether in a $12 \times 75 \mathrm{~mm}$ glass tube. The steroid extract was separated and evaporated on a $37^{\circ} \mathrm{C}$ heating block in a ventilating chemical hood. The extract was dissolved in $1 \mathrm{ml}$ assay buffer, and the amount of progesterone in the extracts was measured according to the protocol of the Progesterone Enzyme Linked Immunoassay Kit (Cayman, Ann Arbor, MI, USA). The cell monolayer in each well was homogenized with lysis 

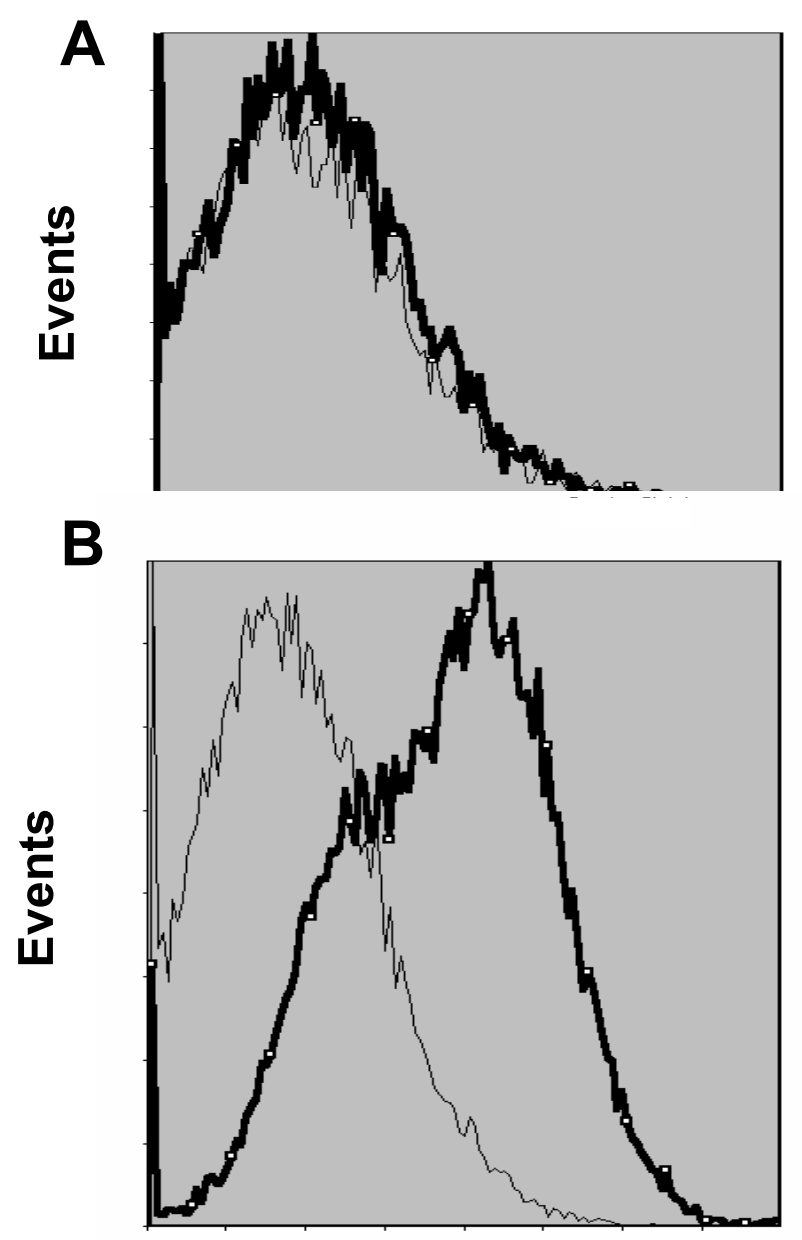

Fluorescence Log

Figure 2 CXCR3 expression in control and CXCL10-transfected MA-10 cells. The expression was analyzed by FACS. The thick black lines indicate cells stained with both antibodies: primary and FITC-conjugated secondary. The thin lines indicate unstained cells. (A) Control MA-10 cells; (B): CXCL10-transfected MA-10 cells.

buffer $(50 \mathrm{mM}$ Tris $\mathrm{HCl}, \mathrm{pH} 7 \cdot 5,150 \mathrm{mM} \mathrm{NaCl}, 1 \mathrm{mM}$ EGTA, 1\% NP-40, 0.25\% sodium deoxycholate, $2 \mu \mathrm{g} / \mathrm{ml}$ aprotinin, $1 \mu \mathrm{g} / \mathrm{ml}$ leupeptin and $100 \mu \mathrm{g} / \mathrm{ml} \mathrm{PMSF}$ ) at $4{ }^{\circ} \mathrm{C}$ for $30 \mathrm{~min}$, and their protein concentrations were determined with the Bicinchoninic Acid Protein Assay Kit (Pierce Biochemicals, Rockford, IL, USA).

\section{Western blot analysis}

The cell culture media of control and transfected cells were collected and recentrifuged to remove any insoluble material. The proteins of the media were then concentrated by precipitation with cold acetone and dissolved in ice-cold lysis buffer. The CXCL10 protein in the concentrated cell medium was detected by Western blot analysis, as described previously (Chen et al. 2003). Recombinant rat CXCL10 (Santa Cruz Biotechnology, Santa Cruz, CA, USA) was used as a positive control. Goat antirat CXCL10 polyclonal antibody (Santa Cruz Biotechnology) and HRP-conjugated bovine antigoat secondary antibody (Santa Cruz Biotechnology) were used for blotting, and Chemiluminescence Luminol Reagent (Santa Cruz Biotechnology) was used for detection.

\section{Fluorescence-activated cell sorter (FACS) analysis}

Flow cytometry was performed with a Coulter Epics $\times$ L-MCL flow cytometer at the Flow Cytometry Core Laboratory, South Carolina Cancer Center, University of South Carolina, by the procedure described by Risberg et al. (2000). Briefly, the cells were lightly trypsinized, fixed in 70\% ethanol, washed and treated with antimouse CXCR3 goat polyclonal IgG antibody (Santa Cruz Biotechnology) followed by a wash with PBS containing 1\% bovine serum albumin (BSA) and incubation with fluorescein isothiocyanate-conjugated rabbit antigoat IgG (Santa Cruz Biotechnology). This was followed by a wash with PBS containing 1\% BSA. The cells were resuspended in PBS and passed through a cell strainer (35 $\mu \mathrm{m}$ nylon mesh) (Fisher Scientific). The single-cell suspensions were then subjected to FACS.

\section{$\left.P^{3} H\right]$ Thymidine incorporation into DNA}

$\left[{ }^{3} \mathrm{H}\right]$ Thymidine incorporation was measured as previously described (Yang et al. 1999). Cells were cultured in 24-well plates for $48 \mathrm{~h}$. Serum-containing medium was replaced with a serum-free medium containing IGF-I $(100 \mathrm{ng} / \mathrm{ml})$ and BSA $(100 \mu \mathrm{g} / \mathrm{ml})$, and incubated for $48 \mathrm{~h}$. $\left[{ }^{3} \mathrm{H}\right]$ Thymidine (Amershambiosciences.com; $0.5 \mu \mathrm{Ci} / \mathrm{ml}$ ) was added, and incubation was continued for $6 \mathrm{~h}$. Unincorporated $\left[{ }^{3} \mathrm{H}\right]$ thymidine was removed by aspirating with cold 5\% trichloroacetic acid. $\left[{ }^{3} \mathrm{H}\right]$ Thymidine incorporation into cellular DNA was measured by dissolving cell material in $0.5 \mathrm{M} \mathrm{NaOH}$ and measuring radioactivity in a Wallac liquid scintillation counter (Pharmacia LKB, Gathersburg, MD, USA). All data points are the average of three experiments, and each experiment was carried out with six replicates.

\section{Statistical analyses}

Results are the means \pm S.E.M. of 4-6 separate experiments. One-way ANOVA followed by the Newman-Keuls multiple comparison test was used for statistical analyses (GraphPad Prism, Version 3.0; GraphPad Software, San Diego, CA, USA). $P \leq 0 \cdot 05$ was considered statistically significant. 


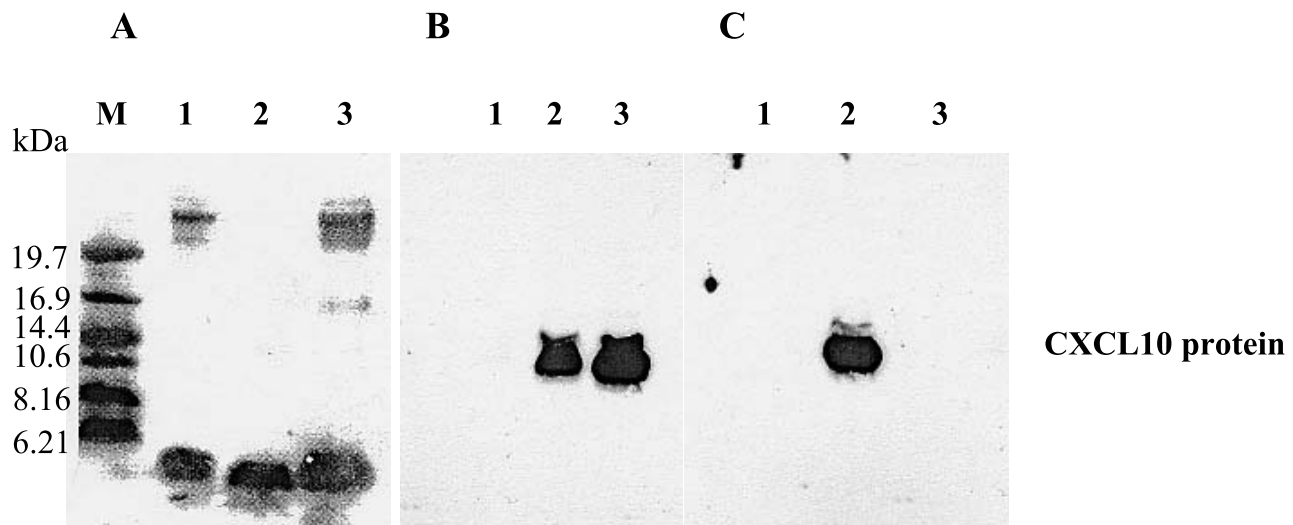

Figure 3 High expression of CXCL10 protein in MA-10 cells with pCMV-mammalian expression vector. MA-10 cells were transfected with pCMV-CXCL10-V5 plasmid. Cell culture medium was concentrated, Western immunoblotted and probed with CXCL10 or V5 antibodies. (A) After SDS-PAGE, the proteins were transferred to PVDF membrane (Amersham Pharmacia Biotech) and stained with 0.5\% Ponceau S solution (Sigma). (B) Immunoblot probed with rat CXCL10 antibody. (C) Immunoblot probed with V5 antibody. Lanes: M, low mol.mass protein markers (BioRad); 1, cell culture medium plus vector; 2, cell culture medium plus pCMV-CXCL10-V5 plasmid; 3, cell culture medium plus recombinant murine CXCL10. The numbers on the left show the mol.mass in kDa of the markers.

\section{Results}

Expression of CXCL10 and CXCR3 $m R N A s$ in the transfected $M A-10$ cells

The expression of mRNA of CXCL10, CXCR3 and S14 was determined by RT-PCR in control and pCMV-CXCL10-V5 or vector-transfected MA-10 cells untreated/treated with $0.2 \mathrm{mM}$ 8-Br-cAMP. The CXCL10 RT-PCR product, a band of $297 \mathrm{bp}$, was expressed in the control cells, but its expression increased

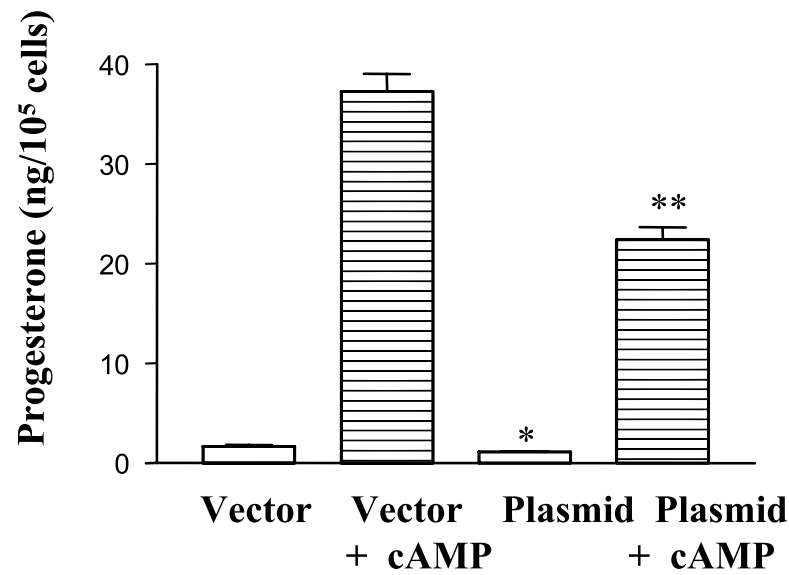

Figure 4 Effect of overexpression of CXCL10 on progesterone synthesis. Data are presented as means \pm S.E.M. of the combined samples from three experiments, each with six replicates. 1, MA-10 cells plus vector; 2, MA-10 cells plus vector plus 8-Br-cAMP $(0 \cdot 2 \mathrm{mM}) ; 3, \mathrm{MA}-10$ cells plus pCMV-CXCL10-V5 plasmid; 4, MA-10 cells plus pCMV-CXCL10-V5 plasmid plus 8-Br-cAMP $(0.2 \mathrm{mM}) .{ }^{*} P<0.01$ and ${ }^{* *} P<0.001$ vs respective controls (ANOVA and Dunnett's test).
30- to 50-fold $(n=6)$ in the pCMV-CXCL10-V5transfected cells (Fig. 1B). Interestingly, overexpression of CXCL10 also increased the expression of its receptor CXCR3 gene, as is evident from Fig. 1C. S14 mRNA expression remained constant in the control and transfected cells. We reported previously that hCG downregulates CXCL10 gene expression by activating adenylate cyclase and increasing cAMP formation $(\mathrm{Hu}$ et al. 1998). In the present study, we found that 8-BrcAMP downregulated CXCL10 mRNA expression and stimulated CXCR3 mRNA expression.

\section{Analysis of CXCR3 expression by FACS}

We further investigated CXCR 3 expression by an alternative method, FACS. The comparative analysis of the control and CXCL10 transfected cells revealed that the transfected cells had significantly increased fluorescence intensity over the control MA-10 cells (Fig. 2). The increased binding of CXCR3 antibody suggests that CXCR3 expression is induced by CXCL10 overexpression.

\section{Expression of CXCL10 protein in transfected MA-10 cells}

After $72 \mathrm{~h}$ of cell culture, the culture medium from control and transfected cells was collected, concentrated, dissolved in the loading buffer and separated by gel electrophoresis under reducing conditions. Western blotting of the medium from CXCL10-transfected cells revealed large bands with electrophoretic mobility slightly slower than that of the recombinant mouse CXCL10 (Fig. 3). This could be explained by the fact that the transfection was 


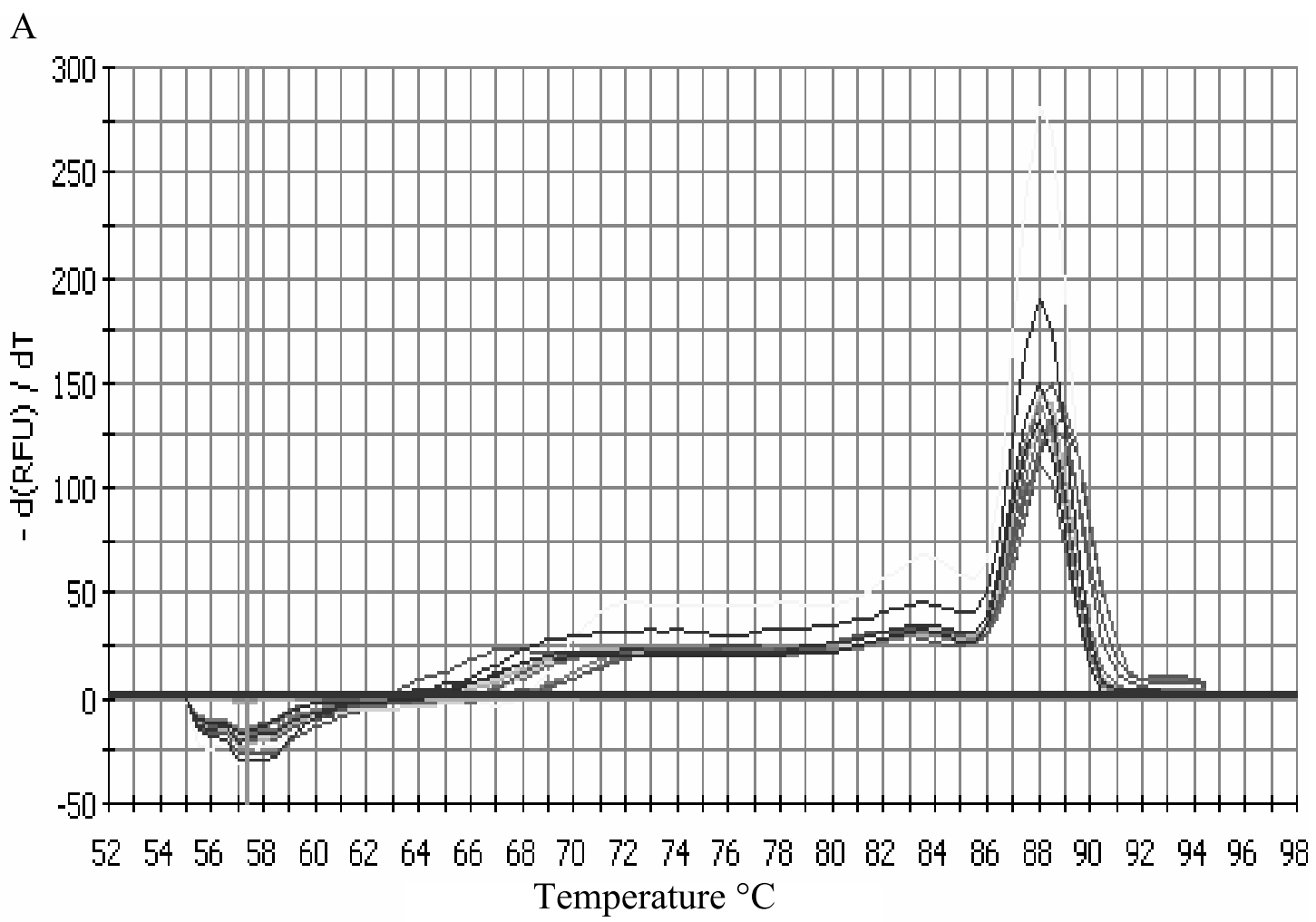

Figure 5 (A).

carried out by the plasmid containing CXCL10 plus V5 antigen and His6. Blotting with V5 antibody revealed large bands in the transfected MA-10 cells, but not in the control or rCXCL10.

Effect of overexpression of CXCL10 on progesterone synthesis and StAR D1 expression

We evaluated the effect of overexpression of CXCL10 on the steroidogenesis in mouse MA-10 Leydig tumor cells, which produce progesterone, but not testosterone in response to cAMP stimulation (Ascoli 1981). Treatment of cells with $0 \cdot 2 \mathrm{mM} 8$-BrcAMP significantly increased progesterone production by 30-40-fold over that of the control cells (Fig. 4). Progesterone secretion by MA-10 cells ranged from $23.2 \pm 1.5 \mathrm{ng}$ in transfected cells to $38.5 \pm 1.7 \mathrm{ng} / \mathrm{ml} \quad\left(1.5 \times 10^{5}\right.$ cells $\left./ \mathrm{ml}\right)$ after $24 \mathrm{~h}$ of stimulation by 8 -Br-cAMP $(0 \cdot 2 \mathrm{mM})$. Thus, the overexpression of CXCL10 resulted in significant inhibition of progesterone production by $40 \%$ (Fig. 4).

We further evaluated the effect of overexpression of CXCL10 on StAR D1 expression in order to study the possible mechanism involved in the effect on $8-\mathrm{Br}-$ cAMP-induced steroidogenesis. We used real-time quantitative RT-PCR, which measures directly the accumulation of the PCR product during the log-linear phase of the reaction and reduces post-PCR manipulations (Bustin 2000, Olney et al. 2002). Fig. 5A shows a melt curve for StAR D1, with one specific product, distinguishing it from nonspecific products and primer dimers. Standard curves of the fluorescence intensity vs $\log$ concentration of mRNA for StAR D1 and S14 were plotted. Fig. 5B shows a representative standard curve for StAR D1. Fig. 5C shows that StAR D1 expression was dramatically induced by 8 -br-cAMP $(0.2 \mathrm{mM})$. The CXCL10-transfected cells showed a $30-40 \%$ decrease in cAMP-induced StAR D1 mRNA levels.

Effect of overexpression of CXCL10 on IGF-I-stimulated cell proliferation

Control and CXCL10-transfected cells were stimulated with IGF-I $(100 \mathrm{ng} / \mathrm{ml})$ for $48 \mathrm{~h}$, and $\left[{ }^{3} \mathrm{H}\right]$ thymidine incorporation into the DNA was measured. IGF-I stimulated $\left[{ }^{3} \mathrm{H}\right]$ thymidine incorporation by $1 \cdot 5-$ to 2 -fold of the control cells. The incorporation was suppressed by $30-$ $40 \%$ by the overexpression of CXCL10 in the transfected cells (Fig. 6). The data suggest a significant decrease in cell proliferation in IGF-I-stimulated cells because of the overexpression of CXCL10. 

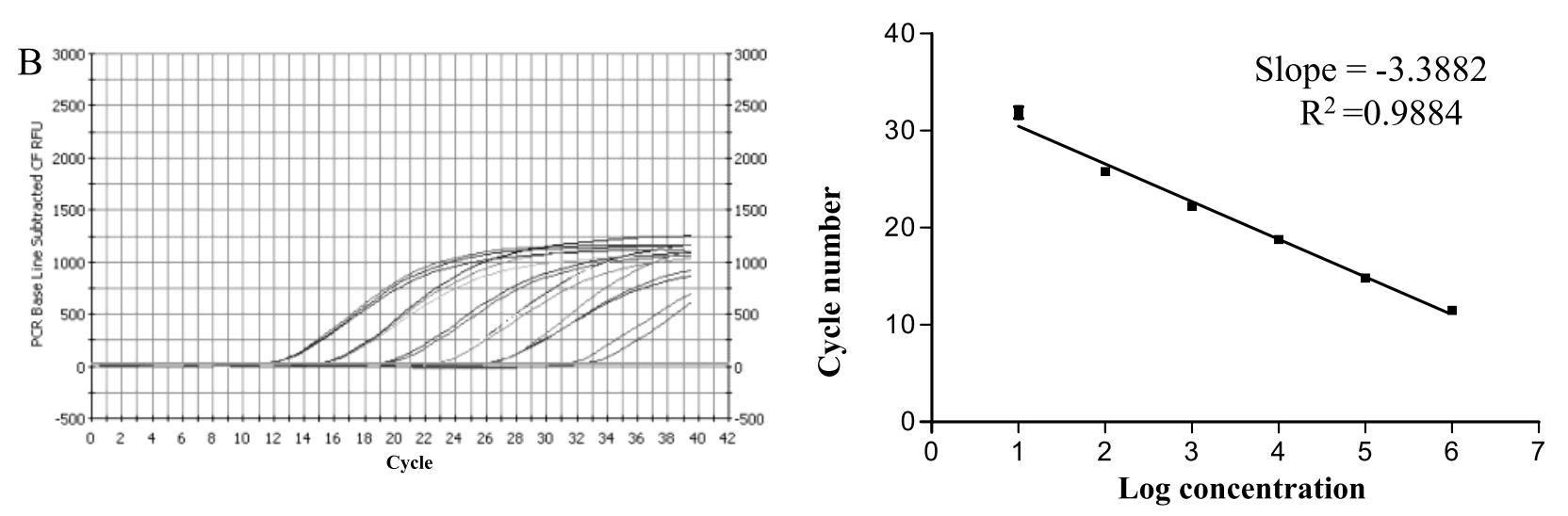

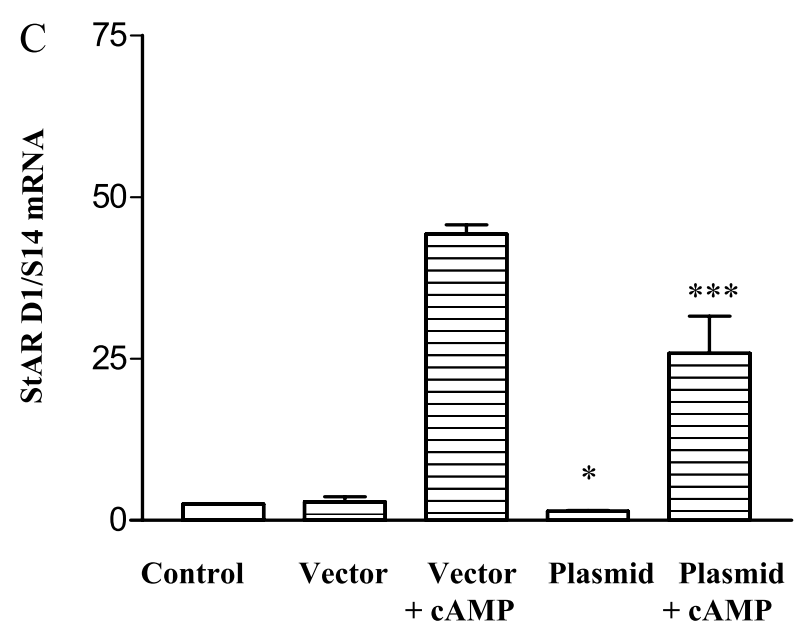

Figure 5 ( $\mathrm{B}$ and $\mathrm{C}$ ).

Figure 5 (A) Melt-curve data collected after StAR D1 amplification. All wells except the zero template control produced a single amplification product. (B) The standard curve was prepared with cDNA containing StAR D1 of decreasing concentrations with 1:10 dilution in triplicates. A plot of the threshold cycle number as a function of the logarithm of the input target quantity shows a linear relationship. (C) Effect of overexpression of CXCL10 on StAR D1 mRNA expression. Control and transfected MA-10 cells were cultured until $70 \%$ confluent. After medium change, cells were treated with $0 \cdot 2 \mathrm{mM} 8$-Br-cAMP and cultured for 24 h. StAR D1/S14 mRNA level was determined by quantitative real-time RT-PCR. The values represent the mean \pm S.E.M. of the combined samples from three experiments, each with three replicates. ${ }^{*} P<0 \cdot 01$ and ${ }^{* *} P<0 \cdot 0001$ vs respective controls.

\section{Discussion}

We have utilized a CMV expression system developed by Invitrogen to overexpress mouse CXCL10 in mouse Leydig tumor MA-10 cells and demonstrate that overexpression of CXCL10 inhibits steroidogenesis and cell growth. The efficiency of this system has been reported previously by Pind et al. (2002). They showed that the overexpression of 3-phosphoglycerate dehydrogenase in pCDNA3.1 vector with CMV promoter caused a dramatic increase in the enzymatic activity in baby hamster kidney (BHK)-21 cells (Pind et al. 2002). Since the CXCL10 protein is produced and secreted from the eukaryotic cells in this study, it is expected to be comparable to its native function.
Our results showed significant amounts of CXCL10 protein secreted in the medium in the CXCL10 transfectants, as estimated by Western blotting. Interestingly, CXCL10 overexpression caused a significant increase in expression of its receptor CXCR3. The mechanism by which receptor expression could be increased by its ligand is intriguing. Recently, Goldberg-Bittman et al. (2004) reported that treatment with recombinant human CXCL10 upregulated the expression of CXCR3 in human breast adenocarcinoma cell lines. A number of reports suggest that activation by a ligand could initiate the activation of transcriptional factors and induce its receptor expression (Wang et al. 2000, Zang et al. 2000, Lisignoli et al. 2002, Nickerson et al. 2003). Keratinocyte growth factor (KGF) treatment enhanced KGF receptor (KGFR) 


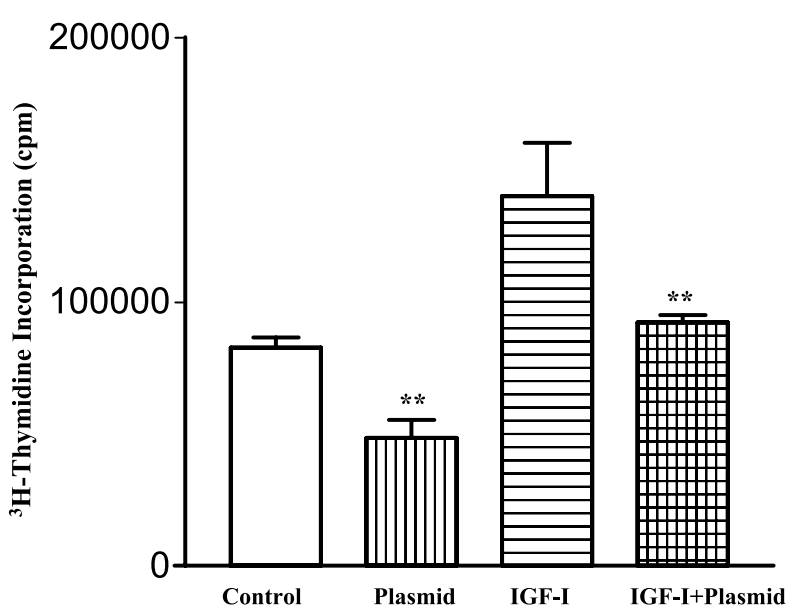

Figure 6 Effect of overexpression of CXCL10 on IGF-I-stimulated cell proliferation. Data are presented as mean \pm S.E.M. of the combined samples from three experiments, each with six replicates. ${ }^{*} P<0 \cdot 001$ as compared with respective controls.

gene expression in MCF-7 breast cancer cells (Zang et al. 2000). Furthermore, Zang et al. demonstrated that KGFR is involved in mediating the KGF-induced motility response in MCF-7 cells. If $\mathrm{KGF}$ is an early signal in the progression to a metastatic phenotype, KGFR may provide a useful therapeutic target to prevent metastatic development in breast cancer (Zang et al. 2003).

It has been observed previously that human colon epithelial cells stimulated with stromal cell-derived factor $1 \alpha \quad(\mathrm{SDF}-1 \alpha)$ and macrophage inflammatory protein (MIP) $-1 \alpha$ or MIP1 $\beta$, which are the chemokine ligands for CXCR 4 or CCR5, upregulated production of the CXC chemokines IL-8 and GRO $\alpha$. Each of these chemokines binds to CCR 5 to elicit autocrine or paracrine effects (Dwinell et al. 1999). In addition to their membrane localization, CXCR 4 and CXCR 5 were observed intracellularly. Such intracellular stores of chemokine receptor may redistribute to the cell membrane in response to stimuli (Dwinell et al. 1999). Increases in the expression of the chemokine receptors CCR 1 and CCR3 in monocytoid cells have been demonstrated in treatment with recombinant IFN- $\alpha$ by RT-PCR and flow cytometry techniques (Zella et al. 1999).

Our data showed that CXCL10 overexpression inhibited IGF-I-induced cell proliferation. Our results are in agreement with the previous report that CXCL10 inhibits endothelial cell proliferation (Luster et al. 1995). Romagnani et al. (1999) have shown that CXCL10 is highly effective in the inhibition of primary human microvascular endothelial cell proliferation. Recently, it has been demonstrated that the growth of CXCL10transduced melanoma cells was markedly diminished compared with the parental or null-transduced cells. These findings suggest that CXCL10 gene therapy might be effective in patients with cancer (Feldman et al. 2002). Previously, it has been shown that CXCL10 and MIG mimic the antitumor effects of IL-12 (Kanegane et al. 1998, Tannebaum et al. 1998, Palmer et al. 2001). Neutralizing antibodies to CXCL10 and MIG partially abrogated IL-12-mediated regression in the RENCA model (Tannebaum et al. 1998).

CXCL10 is expressed in a wide variety of cell types in response to administration of lipopolysaccharide (LPS) (Ohmori \& Hamilton 1990, Vanguri \& Farber 1990), IFN- $\gamma$ and TNF (Ohmori et al. 1993, Luster 1998). Any nucleated cell is capable of producing at least some chemokines constitutively or upon activation (Gangur et al. 2002). A majority of chemokines with proinflammatory activities is induced upon cellular activation by inflammatory stimuli (Moser \& Loetscher 2001).

In the present study, overexpression of CXCL10 decreased 8-Br-cAMP-stimulated progesterone synthesis and inhibited StAR D1 expression. Previously, we have reported that CXCL10 antisense oligonucleotides enhanced basal and hCG-induced testosterone formation in rat Leydig cells ( $\mathrm{Hu}$ et al. 1998). This suggested that endogenous CXCL10 has an inhibitory effect on Leydig cell steroidogenesis. CXCL10 is expressed in rat Leydig cells and may have paracrine and autocrine effects on testicular function.

In summary, we have shown that overexpression of CXCL10 suppresses IGF-I-induced cell proliferation, 8-Br-cAMP-induced steroidogenesis and StAR D1 expression. Although further studies are necessary to elucidate the potential mechanisms of the effects of CXCL10 on the expression of CXCR 3 and StAR D1, the regulatory effect of CXCL10 on steroidogenesis may contribute to the development of androgen-modulating therapeutic strategies in prostate cancer.

\section{Acknowledgements}

This study was supported by the US Department of Veterans' Affairs Medical Research Fund ( $\mathrm{T} L$ ). The authors declare that there is no conflict of interest that would prejudice the impartiality of this scientific work.

\section{References}

Angiolillo A, Sgadari C, Taub D, Liao F, Farber J, Maheshwari S, Kleinman H, Reaman G \& Tosato G 1995 Human interferon-inducible protein-10 is a potent inhibitor of angiogenesis in vivo. Journal of Experimental Medicine 182 185-192.

Ascoli M 1981 Characterization of several clonal lines of cultured Leydig tumor cells: gonadotropin receptors and steroidogenic responses. Endocrinology 108 88-95.

Booth V, Keizer DW, Kamphuis MB, Clark-Lewis I \& Sykes BD 2002 The CXCR3 binding chemokines IP-10/CXCL10: structure and receptor interactions. Biochemistry 41 10418-10425. 
Bustin SA 2002 Absolute quantification of mRNA using real-time reverse transcription polymerase chain reaction assays. Journal of Molecular Endocrinology 25 169-193.

Chen Y, Nagpal ML \& Lin T 2003 Expression and regulation of glucose transporter 8 in rat Leydig cells. Journal of Endocrinology 179 $63-72$.

Dwinell MB, Eckmann L, Leopard JD, Varki NM \& Kagnoff MF 1999 Chemokine receptor expression by human intestinal epithelial cells. Gastroenterology 117 359-367.

Farber JM 1997 Mig and IP-10 CXC: chemokines that target lymphocytes. Journal of Leukocyte Biology 61 246-257.

Feldman AL, Friedl J, Lans TE, Libutti SK, Lorang D, Miller MS, Turner EM, Hewitt SM \& Alexander HR 2002 Retroviral gene transfer of interferon-inducible protein 10 inhibits growth of human melanoma xenografts. International Journal of Cancer 99 149-153.

Gangur V, Birmingham NP \& Thanesvorakul S 2002 Chemokines in health and disease. Veterinary Immunology and Immunopathology $\mathbf{8 6}$ 127-136.

Ganju RK, Brubaker SA, Meyer J, Dutt P, Yang Y, Qin S, Newman W \& Groopman JE 1998 The $\alpha$-chemokine, stromal cell-derived factor- $1 \alpha$, binds to the transmembrane $\mathrm{G}$ protein-coupled CXCR 4 receptor and activates multiple signal transduction pathways. Journal of Biological Chemistry 273 23169-23175.

Goffic RL, Mouchel T, Aubry F, Patard JJ, Ruffault A, Jegou B \& Samson M 2002 Production of the chemokines monocyte chemotactic protein-1, regulated on activation normal $\mathrm{T}$ cell expressed and secreted protein, growth-related oncogene, and interferon- $\gamma$-inducible protein-10 is induced by the Sandai virus in human and rat testicular cells. Endocrinology 143 1434-1440.

Goldberg-Bittman L, Neumark E, Sagi-Assif O, Azenshtein E, Meshel T, Witz IP \& Ba-Baruch A 2004 The expression of the chemokine receptor CXCR 3 and its ligand CXCL10 in human breast adenocarcinoma cell lines. Immunology Letters 92 171-178.

Hu J, You S, Li W, Wang D, Nagpal ML, Mi Y, Liang P \& Lin T 1998 Expression and regulation of interferon- $\gamma$-inducible protein-10 (IP-10) gene in rat Leydig cells. Endocrinology 139 3637-3645.

Kanegane C, Sgadari G, Kanegane H, Teruya-Feldstein J, Yao L, Gupta G, Farber JM, Lio F, Lio L \& Tosato G 1998 Contribution of the CXC chemokines IP-10 and MIG to the antitumor effects of IL-12. Journal of Lenkocyte Biology 64 384-392.

Kozak M 1991 Structural features in eukaryotic mRNAs that modulate the initiation of translation. Journal of Biological Chemistry 266 19867-19870.

Lisignoli G, Toneguzzi S, Grassi F, Piacentini A, Tschon M, Cristino S, Gualtieri G \& Facchini A 2002 Different chemokines are expressed in human arthritic bone biopsies: IFN-gamma and IL-6 differently modulate IL-8, MCP-1 and RANTES production by arthritic osteoblasts. Cytokine 20 231-238.

Luster AD 1998 Chemokines: chemotactic cytokines that mediate inflammation. New England Journal of Medicine 338 436-445.

Luster AD, Greenbergi SM \& Leder P 1995 The IP-10 chemokine binds to a specific cell surface heparin sulfate site shared with platelet factor 4 and inhibits endothelial cell proliferation. Journal of Experimental Medicine 182 219-231.

Mamchaoui K, Makhloufi Y \& Saumon G 2002 Glucose transporter gene expression in freshly isolated and cultured rat pneumocytes. Acta Physiologica Scandinavica 175 19-24.

Moser B \& Loetscher P 2001 Lymphocyte traffic control by chemokines. Nature Immunology 2 123-128.

Murphy PM, Baggiolini M, Charo IF, Hebert CA, Horuk R, Matsushima K, Miller LH, Oppenheim JJ \& Power CA 2000 International Union of Pharmacology. XXII. Nomenclature for chemokines receptors. Pharmacological Reviews 52 145-176.

Narumi S, Wyner LM, Stoler MH, Tannenbaum CS \& Hamilton TA 1992 Tissue-specific expression of murine IP-10 mRNA following systemic treatment with interferon- $\gamma$. Journal of Leukocyte Biology $\mathbf{5 2}$ $27-33$.
Nickerson T, Chang F, Lorimer D, Smeekens SP, Sawyers CL \& Pollak M 2003 In vivo progression of LAPC-9 and LNCaP prostate cancer models to androgen independence is associated with increased expression of insulin-like growth factor-I (IGF-I) and IGF-I receptor (IGF-IR). Cancer Research 61 6276-6280.

Ohmori Y \& Hamilton TA 1990 A macrophage LPS-inducible early gene encodes the murine homologue of IP-10. Biochemical and Biophysical Research Communications 168 1261-1267.

Ohmori Y \& Hamilton TA 1995 The interferon-stimulated response element and a $\mathrm{\kappa B}$ site mediate synergistic induction of murine IP-10 gene transcription by IFN- $\gamma$ and TNF- $\alpha$. Journal of Immunology 154 5235-5243.

Ohmori Y, Wyner L, Narumi S, Armstrong D, Stoler M \& Hamilton TA 1993 Tumor necrosis factor- $\alpha$ induces cell type and tissue-specific expression of chemotractant cytokines in vivo. American Journal of Pathology 142 861-870.

Olney RC, Mougey EB, Wang J, Shulman DI \& Sylvester JE 2002 Using real-time, quantitative PCR for rapid genotyping of the steroid 21-hydroxylase gene in a north Florida population. Journal of Clinical Endocrinology and Metabolism 87 735-741.

Palmer K, Hitt M, Emtage PCR, Gyorffy S \& Gauldie J 2001 Combined CXC chemokines and interleukin-12 gene transfer enhances antitumor immunity. Gene Therapy 8 282-290.

Pind S, Slominski E, Mauthe J, Pearlman K, Swoboda KJ, Wilkins JA, Sauder P \& Natowicz MR 2002 V490 M, a common mutation in 3-phosphoglycerate dehydrogenase deficiency, causes enzyme deficiency by decreasing the yield of mature enzyme. Journal of Biological Chemistry 277 7136-7148.

Risberg B, Davidson B, Dong HP, Nesland JM \& Berner A 2000 Flow cytometric immunophenotyping of serous effusions and peritoneal washings: comparison with immunocytochemistry and morphological findings. Journal of Clinical Pathology $\mathbf{5 3}$ 513-517.

Romagnani P, Beltrami C, Annunziato F, Lasgni L, Luconi M, Galli G, Cosmi L, Maggi E, Salvadori M, Pupilli C \& Serio M 1999 Role for interactions between IP-10/Mig and CXCR3 in proliferative glomerulonephritis. Journal of the American Society of Nephrology 10 2518-2526.

Sgadari C, Angiolillo AL, Cherney BW, Pike SE, Farber JM, Koniaris LG, Vanguri P, Burd PR, Sheikh N, Gupta G, Teruya-Feldstein J \& Tosato G 1996 Interferon-inducible protein-10 identified as a mediator of tumor necrosis in vivo. PNAS 93 13791-13796.

Soejima K \& Rollins BJ 2001 A functional IFN-gamma-inducible protein-10/CXCL10-specific receptor expressed by epithelial and endothelial cells that is neither CXCR 3 nor glycosaminoglycan. Journal of Immunology 167 6576-6582.

Tamaru M, Tominaga Y, Yatsunami K \& Narumi S 1998 Cloning of the murine interferon-inducible protein 10 (IP-10) receptor and its specific expression in lymphoid organs. Biochemical and Biophysical Research Communications 25 41-48.

Tannenbaum CS, Tubbs R, Armstrong D, Finke JH, Bukowski RM \& Hamilton TA. 1998 The CXC chemokines IP-10 and Mig are necessary for IL-12 mediated regression of mouse RENCA tumor. Journal of Immunology 161 927-932.

Vanguri P \& Farber JM 1990 Identification of CRG-2, an interferon-inducible mRNA predicted to encode a murine monokine. Journal of Biological Chemistry 265 15049-15057.

Wang X, Yue TL, Ohlstein EH, Sung CP \& Feuerstein GZ 1996 Interferon-inducible protein-10 involves vascular smooth muscle cell migration, proliferation, and inflammatory response. Journal of Biological Chemistry 27 24286-24293.

Wang X, Li X, Schmidt DB, Foley JJ, Barone FC, Ames RS \& Sarau HM 2000 Identification and molecular characterization of rat CXCR3 receptor expression and interferon-inducible protein-10 binding are increased in focal stroke. Molecular Pharmacology $\mathbf{5 7}$ 1190-1198. 
Yang F, Johnson BJ, White ME, Hathaway MR \& Dayton WR 1999 Effect of insulin-like growth factor (IGF-I) and Des (1-3)IGF-I on the level of IGF binding protein-3 and IGF binding protein-3 mRNA in cultured porcine embryonic muscle cells. Journal of Cellular Physiology 178 227-234.

Zang XP, Lerner MR, Brackett DJ \& Pento JT 2000 Antisense KGF-induced gene expression in MCF-7 cells using cDNA expression arrays. Breast Cancer Research and Treatment 64110.

Zang XP, Lerner MR, Dunn T, Brackett DJ \& Pento JT 2003 Antisense K GFR oligonucleotide inhibition of KGF-induced motility in breast cancer cells. Anticancer Research 23 4913-4920.
Zella D, Barabitskaja O, Casareto L, Romerio F, Secchiero P, Reitz MS Jr, Gallo RC \& Weichoid FF 1999 Recombinant IFN- $\alpha$ (2b) increases the expression of apoptosis receptor CD95 and chemokine receptors CCR 1 and CCR3 in monocytoid cells. Journal of Immunology 163 3169-3175.

Received 23 August 2004

Accepted 7 September 2004 